\title{
Economic losses due to bovine mastitis in Dutch dairy herds
}

\author{
M.H.W. SCHAKENRAAD \& A.A. DIJKHUIZEN
}

Department of Farm Management, Wageningen Agricultural University, Hollandseweg 1, $6706 \mathrm{KN}$ Wageningen, Netherlands

Received 21 July 1989; accepted 12 October 1989

\begin{abstract}
Current annual losses due to mastitis in Dutch dairy herds were calculated to average Dfl. 136 per cow per year, which equals about $12 \%$ of net return on labour and management per cow on a typical farm. Reduction in milk and fat yield accounts for $70 \%$ of these losses. Streptococcal infections were found to have the highest economic impact, causing almost $40 \%$ of total losses. More information should become available to estimate differences in losses between farms.
\end{abstract}

Keywords: mastitis, economic losses, dairy cattle

\section{Introduction}

Mastitis is commonly recognized as a major economic disease in dairy cattle. For Dutch conditions, losses were previously quantified on Dfl. 125 per cow per year, which equaled about $15 \%$ of net return on labour and management per cow on a typical farm (Dijkhuizen \& Renkema, 1977). Since then various prices and production circumstances have changed, and more literature became available on the incidence and effects of mastitis.

In most economic calculations the number of somatic cells in the milk was used as a major criterion for the presence and seriousness of mastitis. In the literature, however, there is a discussion going on whether this criterion is still appropriate. The number of cells was found to be influenced by several other factors, such as production level, age and breed (Brolund, 1985).

In this paper, current economic losses in Dutch dairy cattle of both infections with and without clinical signs are estimated, using pathogens in the milk as the major diagnostic criterion. Four different types of pathogens are being considered: coliform, streptococcal, staphylococcal, and Corynebacterium pyogenes. Clinical cases in which no pathogens could be detected are defined as bacteriologically negative. 


\section{Economic framework and input data}

The economic effects of mastitis can be divided into three major categories: (1) reduced milk receipts, (2) costs for treatment, and (3) premature culling. Input data were derived from various references, reliable for Dutch conditions, and summarized in Table 1.

As shown in Table 1, total frequency of clinical mastitis is estimated to average 28 cow cases per 100 cows per year, with $28 \times 1.3=36$ quarters being involved. Streptococcal infections appear to be the most frequent. The estimated decrease in total milk production is taken to be $23 \%$, ranging from $17 \%$ for coliform to $48 \%$ for Corynebacterium pyogenes. Fat contents of the milk is assumed to be reduced by over $4 \%$ (Hoare, 1982). For each $\mathrm{kg}$ of milk not produced, a saving of $0.5 \mathrm{~kg}$ of concentrates is taken into account. Treatment costs are considered to include veterinary fees, drug expenses, and farmer's labour. Milk from cows treated with

Table 1. Major input data for clinical mastitis.

\begin{tabular}{lclll}
\hline Type of pathogen & Frequency & $\begin{array}{l}\text { Infected } \\
\text { quarters } \\
\text { per case }\end{array}$ & $\begin{array}{l}\text { Annual milk } \\
\text { decrease per } \\
\text { quarter (\%) }\end{array}$ & $\begin{array}{l}\text { Culling rate } \\
(\%)\end{array}$ \\
Coliform & 7.0 & 1.1 & 17 & 14 \\
Streptococcal & 10.8 & 1.3 & 22 & 10 \\
Staphylococcal & 3.0 & 1.4 & 26 & 14 \\
C. pyogenes & 1.6 & 1.1 & $48^{2}$ & 80 \\
Bact. negative & 5.6 & 1.3 & 21 & 12 \\
Total/Average & 28.0 & 1.3 & 23 & 14 \\
\hline
\end{tabular}

1 Percentage cow cases per year.

2 Next lactation.

Table 2. Calculated annual losses due to mastitis (Dfl.)

\begin{tabular}{llll}
\hline Type of pathogen & \multicolumn{2}{l}{$\begin{array}{l}\text { Calculated annual loss } \\
\text { per infected cow }\end{array}$} & $\begin{array}{l}\text { Total calculated annual loss } \\
\text { per 100-cow herd }\end{array}$ \\
\cline { 2 - 3 } $\begin{array}{l}\text { with clinical } \\
\text { signs }\end{array}$ & $\begin{array}{l}\text { without } \\
\text { clinical signs }\end{array}$ & \\
Coliform & 355 & - & $2440(18 \%)$ \\
Streptococcal & 446 & 66 & $5300(39 \%)$ \\
Staphylococcal & 504 & 79 & $2070(15 \%)$ \\
C. pyogenes & 886 & - & $1420(17 \%)$ \\
Bact. negative & 424 & - & $2360(11 \%)$ \\
Total/Average & 450 & 71 & $13600(100 \%)$ \\
\hline
\end{tabular}


anti-biotics is not delivered to the factory for 5 days, but fed to young calves. This reduces the losses from otherwise discarded milk.

On an average $14 \%$ of the cows with clinical mastitis are culled, as shown in Table 1. C. pyogenes ranks by far the highest with a culling rate of $80 \%$. The loss of culling is the difference of (1) the income that a particular cow could earn during her remaining expected life, had the reason for replacement not presented itself given normal probabilities of disposal due to other reasons - and (2) the expected average income of replacement animals. Van Arendonk (1985) calculated the costs of premature disposal to average Dfl. 430 per culled cow.

Per year, 11 cows (and 15 quarters) per 100 cows have infections without any clinical signs, of which $60 \%$ is caused by streptococcal and $40 \%$ by staphylococcal bacteria. Losses are restricted to milk reduction (4.6\% per lactation) and fat decline (1.9\% per lactation). Mastitis without clinical signs is difficult to detect. Therefore, treatment costs nor premature culling are being included in the calculations.

\section{Results}

Calculated annual losses due to mastitis are summarized in Table 2 . Per clinically infected cow the $C$. pyogenes pathogen causes by far the highest losses, especially because of its extreme culling rate. Staphylococcal infections rank secondly, due to a combination of a relatively high number of infected quarters per case and a considerable loss in production. Infections without any clinical signs are far less important from an economic point of view.

At farm level, streptococcal infections have the highest economic impact, causing almost $40 \%$ of total losses, while C. pyogenes now ranks the lowest. Their differences in costs per case are outranged by differences in incidence rates.

Total losses per farm are found to average Dfl. 136 per cow per year, which equals about $12 \%$ of net return on labour and management per cow on a typical farm. Reduction in milk and fat yield accounts for $70 \%$ of these losses, $18 \%$ is due to treatment and $12 \%$ is caused by premature culling.

\section{Final remarks}

A quantitative insight into the economic impact of diseases is not only important for a description of the actual situation, but can help to estimate the extent of the losses to be avoided. In particular this is the case if differences between farms are indicated. With respect to mastitis, more farm specific information on the incidence rate and effect on cow performance should become available to estimate these differences. Additional research is also of interest to determine the actual costs and benefits of mastitis control measures.

\section{References}

Arendonk, J.A.M. van, 1985. Studies on the replacement policies in dairy cattle. II. Optimum policy and influence of changes in production and prices. Livestock Production Science 13: 101-121. 
Brolund, L., 1985. Cell counts in bovine milk. Acta Veterinaria Scandinavica, Supplement 80 (thesis). Dijkhuizen, A.A. \& Renkema, J.A., 1977. Economic aspects of diseases and dairy herd health programs in the Netherlands, with special reference to mastitis. Tijdschrift voor Diergeneeskunde 102: 12391248 (Dutch, English summary).

Hoare, R.J.T., 1982. Mastitis: its effect on milk yield, composition and quality. Proceedings Conference on Dairy Production from pasture, Hamilton, pp. 85-97.

This synopsis is based on a student thesis, entitled 'Bedrijfseconomische schade van mastitis in de Nederlandse melkveehouderij' by M.H.W. Schakenraad, Department of Farm Management, Wageningen Agricultural Univerity, Wageningen, 1988, 56 pp., 7 figs., 23 tables, 2 app., 67 refs., in Dutch. Available as paper copy (order R102, $f 20$ including postage) at: NARD, c/o Pudoc, P.O Box 4, $6700 \mathrm{AA}$ Wageningen (telex 45015 bluwg $\mathrm{nl}$ ). 